\title{
The influence of soak temperature and forging lubricant on surface properties of steel forgings
}

\author{
S. Hill ${ }^{1}$ • R. P. Turner ${ }^{2} \cdot$ P. Wardle ${ }^{3}$
}

Received: 28 July 2020 / Accepted: 7 December 2020 / Published online: 28 December 2020

(C) The Author(s) 2020

\begin{abstract}
A small series of ring compression tests were performed on BS970:708M40 alloy steel. The samples were tested using a 2-factor temperature variable, and a 4-factor lubricant variable, as the design parameters. Two differing soak temperatures were used, namely $1030{ }^{\circ} \mathrm{C}$ and $1300{ }^{\circ} \mathrm{C}$ respectively. The lubricants applied at the billet to tooling interface were synthetic water-based, graphite water-based, graphite and molybdenum disulphide viscous grease, and finally, unlubricated samples were tested. The ring compression tests were performed using a traditional drop forging hammer and induction heating to minimise any unintentional process variability. The impact that the two varying process parameters have upon the compression sample was then assessed by measuring each sample's surface hardness and surface roughness prior to and post forging with fully calibrated equipment. It was demonstrated that the higher soak temperature of $1300{ }^{\circ} \mathrm{C}$ yielded a lower surface hardness value and higher surface roughness than the lower soak temperature, $1030^{\circ} \mathrm{C}$. The two water-based lubricants offered negligible change in results compared with the unlubricated forging, strongly suggesting that the lubricants were evaporated off the surface prior to forging. However, the results from the graphite-molybdenum disulphate grease do indicate in particular higher surface roughness than other lubricants, and a non-symmetric distortion pattern.
\end{abstract}

Keyword Forging. Ring compression test. Lubricant. Surface hardness. Surface roughness. Deformation. Friction

\section{Introduction}

Closed die forging operations have been studied comprehensively over many years, to better understand the material flow and deformation in order to optimise processing routes. Doege and Bohnsack [8] gave design rules applicable for different tooling systems to manufacture a variety of components. Douglas and Kuhlmann [9] further gave guidelines for precision hot forging applications, capable of matching tolerances and accuracies of cold forging alternatives. The benefits of hot

S. Hill

stevenhill@whtildesley.com

R. P. Turner

r.p.turner@bham.ac.uk

$1 \quad$ W.H. Tildesley Ltd, Willenhall, UK

2 School of Metallurgy \& Materials, University of Birmingham, Birmingham, UK

3 Mechanical Engineering, University of Wolverhampton, Wolverhampton, UK forging are cost reduction by reducing material usage, reducing forging energy and eliminating certain post-forge processing requirements.

In traditional drop forging operations, the surface properties of the billet, such as hardness and roughness, can be directly influenced by processing parameters, as shown by Allam et al. [1]. These parameters dictate how a material deforms and ultimately the final surface properties observed [21]. The processing conditions such as heat, lubrication and tooling play a major role in this particular area, demonstrated by Groche et al. [11]. However, although these surface properties can be controlled to an extent with post forge processes such as heat treatment [4], it is still good practice to understand what variation can occur to these properties dependent on differing forging parameters.

Utsunomiya et al. [30] have reviewed how an oxide scale film is generated on steel surfaces at elevated temperatures in the presence of air. Because the scale is located at the interface between tool and steel billet during hot working processes, it crucially influences the hot working characteristics [22]. It is known that the friction and heat transfer characteristics in the hot working processes are affected by the presence of scale. 
Further experimental analysis and FE modelling work on steel during hot forging operations were undertaken by Matsumoto et al. [23]. Here the steel employed was a chrome steel JIS SCr420. Under particular conditions the presence of scaleconsidered an undesirable consequence of hot forgingactually has the effect of lubricating the interface and providing a low thermal conductivity barrier to reduce heat loss to the tooling.

Jeong et al. [17] examines how forging dies can be processed to reduce friction, as the metal forming process is always accompanied by heat generation. This heat, due to plastic deformation and the friction of the component/tool interface, results in a complex and changing temperature field. The prediction of these temperature changes is important as they directly affect lubrication conditions. This material behaviour during deformation can impact finished parts or the tools life.

Gronostajski et al. [12] discuss how lubrication is critical to the lifetime of forging tools. In the standard operating procedure during a semi-closed die forging process (upsetting, flattening, etc.), tool lubrication is not utilised as the flow of the material being deformed is uncomplicated. This is not the case in typical die forging, during which the use of a lubricating and cooling agent is required due to the need to minimize the friction for the purpose of precise filling of the tool's impression with the material, as well as insulating the tooling against direct contact with the hot forged material. This coolant layer reduces the heat-sink effect that the cool die has when contacting the hot billet, thus reducing the intensity of the tempering, oxidation and erosion processes.

Jahazi et al. [15] studied the influence of cooling rate during hot forging conditions upon the tensile, charpy V-notch, impact and hardness values for two V-Ti microalloyed steels. It was found that by increasing the cooling rate both the strength and toughness increase. This increase is understood to be caused by the microstructure formed at such conditions, which is mainly composed of non-ferrite transformation products.

The effect of both heating and cooling rates upon the resulting microstructure, and subsequent mechanical properties of steels, has been considered within literature [24, 32]. Heating rates have been demonstrated to play a role in the formation of particular phases including martensite, with quicker heating rates tending to yield improved mechanical properties [32].

For forged 30MSV6 grade steel, the cooling rate was considered and it was shown that at slower cooling rates of $3{ }^{\circ} \mathrm{C} / \mathrm{s}$ acicular ferrite forms which improves strength and ductility. Whilst at faster rates of $15^{\circ} \mathrm{C} / \mathrm{s}$, bainite tends to form which also increases strength, but has a significant decrease in ductility [24].

Linaza et al. [19] has shown that through manipulation of the final formed microstructure, primarily via thermomechanical processing at specific rates, mechanical properties including toughness and hardness can be adapted as required.
The impact that the strain rate induced into the workpiece through the forging operation can have upon the mechanical properties of 304L stainless steel was considered by [27]. For lower strain rate processing, less strengthening occurs, due to the longer processing time. An increase in the strain rate reduces the hardness variation for a given part. The yield strength of $304 \mathrm{~L}$ forged at higher strain rates is less sensitive to temperature variations.

Lastly, modelling techniques such as finite element modelling (FE) have been applied to predict certain outcomes of steel hot forging processes, including the microstructure evolution including recrystallization [16], a prediction of the uniformity of the temperature distribution within the workpiece after forging [7], and a prediction of the quench-induced distortions within large steel forgings using 3D FE software [3].

The steel alloy $708 \mathrm{M} 40$ has a composition as given in Table 1. The sulphur and phosphorus content are undesirable impurities; however, the quantities of this controlled manufacture only offer slight embrittlement [29]. 708M40 is a reasonably widely used alloy, typically across the automotive industries, in components ranging from shafts to gears [26]. It offers reliable high tensile strength in the components it is used to manufacture. It is a hypoeutectoid steel, as it has a carbon composition of lower than $0.76 \mathrm{wt} \%$.

When it is cooled at relatively slow cooling rates, such as air-cooling, it has a microstructure containing proeutectoid ferrite, formed at higher temperatures as the part cools [2], and pearlite, which is formed of interlaying laths of eutectoid ferrite with cementite, which forms at lower temperature during the cooling [2]. The resulting mechanical properties of the formed material, prior to any deformation or forging operations, are dependent upon the heat treatment condition of the alloy, however in its $\mathrm{T}$ condition, has a typical Brinell Hardness range of between 248 and 302 [13].

Thus, the intention of this work is to experimentally measure the impact that the variation of two process parameters, namely the billet temperature and the lubricant used at the tooling to billet interface, has on the surface hardness and surface roughness properties of the as-forged BS970:708M40 alloy steel.

\section{Experimental work}

A series of ring compression tests were performed according to a full-factorial DOE matrix of a 2 -factor test. The 1 st

Table 1 Chemical composition range of 708M40 steel

\begin{tabular}{lllllllll}
\hline Element & $\mathrm{C}$ & $\mathrm{Mn}$ & $\mathrm{Si}$ & $\mathrm{Cr}$ & $\mathrm{Mo}$ & $\mathrm{S}$ & $\mathrm{P}$ & $\mathrm{Fe}$ \\
Min. wt\% & 0.36 & 0.7 & 0.1 & 0.9 & 0.15 & 0 & 0 & $\mathrm{Bal}$ \\
Max. wt\% & 0.44 & 1.0 & 0.35 & 1.2 & 0.25 & 0.04 & 0.035 & \\
\hline
\end{tabular}


variable input was the forging temperature, a 2-level factor $\left(1030^{\circ} \mathrm{C}, 1300{ }^{\circ} \mathrm{C}\right)$, and the 2 nd input was lubricant material, a 4-level factor (unlubricated, synthetic water-based, graphite water-based, graphite molybdenum grease), yielding 8 experimental conditions. Thirty-six samples were machined in total, allowing for multiple repeat ring compression tests to be performed on samples in the eight differing conditions. The material used for the experiment was BS970:708M40 in 'T' condition (Bright Bar), as per table 7 within the British Standard PD 970:2005 [25]. This material was supplied in $\varnothing 65 \mathrm{~mm}$ bright drawn round bar and was then sewn to individual lengths of $23 \mathrm{~mm}$. It was then machined on a Feeler FTC 20 New Computer Numerically Controlled (CNC) lathe to finished machine sizes as shown in Fig. 1. The samples were then engraved to ensure full traceability was maintained throughout the experiment. Each engraving code is detailed in Table 2.

An induction heating loop was used to ensure that for each forging temperature condition, a repeatable temperature was achieved for each sample prior to the forging operation, and a Cyclops L Portable pyrometer (Model C100L) was used to record the sample temperature immediately after heating, to verify that the induction heater had correctly heated the specimens. Figure 2a displays the induction equipment, and Fig. $2 \mathrm{~b}$ the pyrometer. Repeatability and accuracy of wellmaintained induction heaters are reported by Larrabee [18] to be good, and the addition of a surface measurement reading from the pyrometer allows further assurance that any internal non-uniformity would be indicated by surface nonuniformities.

For the 1 st test temperature, $1030{ }^{\circ} \mathrm{C}$, the induction heating unit was set to deliver a constant $5.4 \mathrm{~kW}$ of power over a duration of $65 \mathrm{~s}$, yielding approximately $350 \mathrm{~kJ}$ of energy. The 2 nd test temperature, $1300{ }^{\circ} \mathrm{C}$, had the induction heating unit set to deliver a constant $5.5 \mathrm{~kW}$ of power over a duration of $75 \mathrm{~s}$, yielding $413 \mathrm{~kJ}$ of energy.

The drop forging hammer (Fig. 2d) used for the ring compression tests was a Massey 2.2 MSC drop hammer, owned by W.H. Tildesley Ltd of Willenhall. The hammer operates by allowing a tup weighing $1150 \mathrm{~kg}$ to fall under gravitational acceleration from a pre-defined height dependent on varying die thicknesses. In this case, the total drop height when taking into account the top and bottom die was $1.65 \mathrm{~m}$ (bottom die fixed into the hammers bolster/anvil is shown in Fig. 2c). Additionally to the tup weight, the flat top die that was fixed into the tup weighed $184 \mathrm{~kg}$ therefore giving a total mass of $1334 \mathrm{~kg}$. Thus, the system was calibrated to deliver $2200 \mathrm{~kg} \mathrm{~m}$ falling under gravitational acceleration, giving a blow energy of $E=\mathrm{mg} \mathrm{h}=21.5 \mathrm{~kJ}$.

The flat die was measured for its temperature uniformity and to ensure it was above the required $100{ }^{\circ} \mathrm{C}$. This would allow for the water in the water-based lubricants to evaporate off, leaving the layer of either synthetic or graphite lubricant to be present during the forging. Again this was performed with a pyrometer. Each specimen was then loaded onto the flat die using the same manual operator, who used a consistent travel speed and time to move the sample from induction heater to forging die. Figure $2 \mathrm{e}$ shows the heated sample in place being sprayed with lubricant. The specimen was then subjected to one single forging blow.

Both of the water-based lubricants were mixed to a ratio of one-part lubricant to five parts water as per the relevant technical data sheet. The density of each lubricant mix was also measured with a hydrometer to ensure that a like-for-like comparison between the synthetic and graphite in water lubricants was achieved. The graphite and molybdenum disulphide lubricant was in the form of a grease; therefore, it was challenging to apply an even amount to the die. A small quantity of the grease, representative of a sensible coating as used in commercial drop-forging activities, was brushed onto the bottom and top die just to ascertain its effectiveness compared with the water-based lubricants. The heated sample ignited upon contact with this lubricant (see Fig. 2f). The complete layout of the experiment is shown in Fig. 3.

Surface roughness and hardness tests were then performed using a Mitutoyo Surface Finish - Surftest 211 Roughness Tester and Proceq Equotip R3 Surface hardness tester respectively. They were both calibrated by an independent test house to ensure results obtained were accurate. Each sample's surface hardness and roughness result was recorded onto specific
Table 2 Process parameters for the series of 36 forging trials, at 8 different processing conditions

\begin{tabular}{llll}
\hline Sample & Temperature $\left({ }^{\circ} \mathrm{C}\right)$ & Lubricant & No. of repeats \\
\hline $1 \mathrm{U}$ & 1030 & Unlubricated & 5 \\
$1 \mathrm{~S}$ & 1030 & Synthetic water-based & 5 \\
$1 \mathrm{G}$ & 1030 & Graphite water-based & 5 \\
$1 \mathrm{GM}$ & 1030 & Graphite-Molybdenum disulphide grease & 3 \\
$2 \mathrm{U}$ & 1300 & Unlubricated & 5 \\
$2 \mathrm{~S}$ & 1300 & Synthetic water-based & 5 \\
$2 \mathrm{G}$ & 1300 & Graphite water-based & 5 \\
$2 \mathrm{GM}$ & 1300 & Graphite-Molybdenum disulphide grease & 3 \\
\hline
\end{tabular}


Fig. 1 Ring compression sample sizes
Plan View

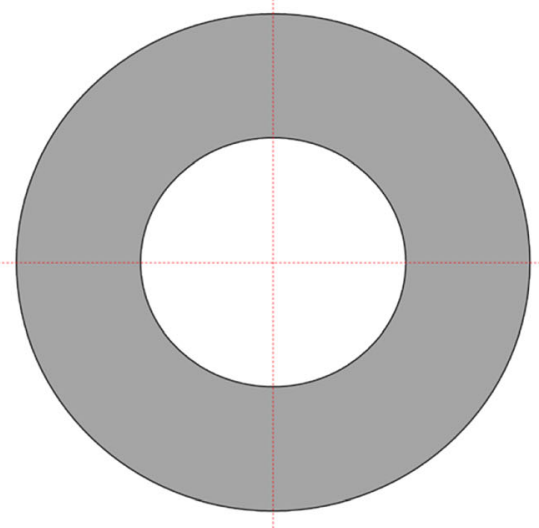

Cross-section View

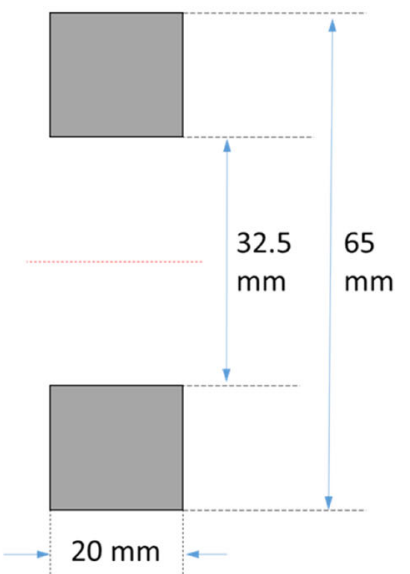

dimensional reports in preparation for analytical work to take place. Each measurement was made on a clean inspection station, and samples were measured in a repeatable manner to ensure accuracy and fairness of comparison.

\section{Theory}

As discussed earlier, the method of heating used, and importantly the rate of heating and cooling of the workpiece, can have a significant role in the final mechanical properties of the part. As such, it becomes of interest to understand the thermal energy imparted, and the time taken, to generate understanding of the heating rate involved within the induction heating operation carried out within this work. This level of process understanding also eliminates the dependence upon operator experience and any operator-related errors that may lead to unrepeatable process conditions.

In order to prove why the $5.4-\mathrm{kW}$ thermal power for $65 \mathrm{~s}$ yielded a sample heated to a uniform $1030{ }^{\circ} \mathrm{C}$, and similarly why the $5.5-\mathrm{kW}$ thermal power heated for $75 \mathrm{~s}$ yielded a sample heated to a uniform $1300{ }^{\circ} \mathrm{C}$, one must consider the fundamental material properties. The thermal energy equation allows us to calculate the thermal energy required to heat a known mass of material by a specific temperature, and this is shown in Eq. 1.

$Q_{1,2}=m c_{p} \Delta T$

where $Q_{1,2}$ is the thermal energy required to heat from reference temperature 1 to temperature $2, m$ is mass, $c_{p}$ is specific heat (often temperature-dependent function) and $\Delta T$ is the temperature rise. The mass of the cylinder can be found from
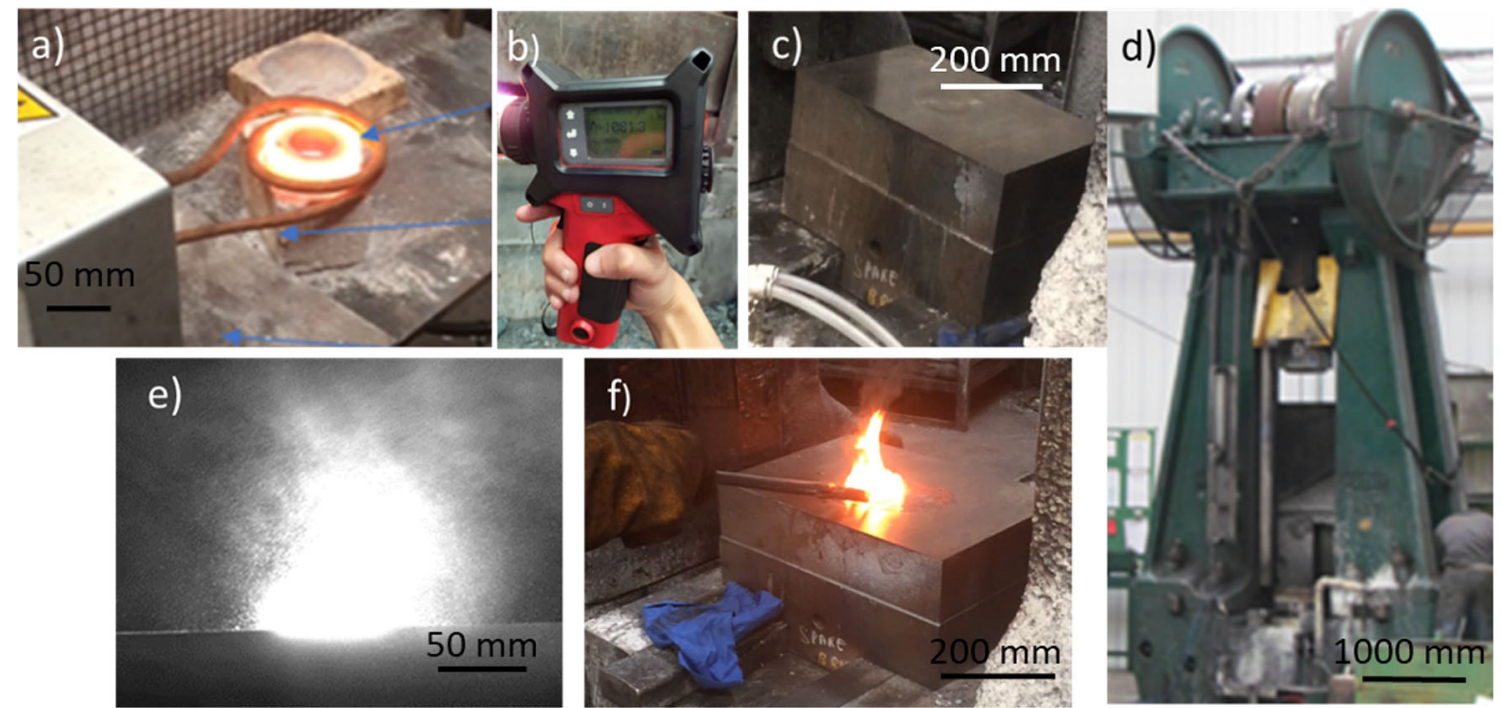

Fig. 2 a Induction heating unit and heated sample. b Pyrometer. $\mathbf{c}$ Flat die. d Drop forging machine. e Water-based lubricant being sprayed on to sample. f Steel sample igniting upon contact with graphite molybdenum disulphide grease 


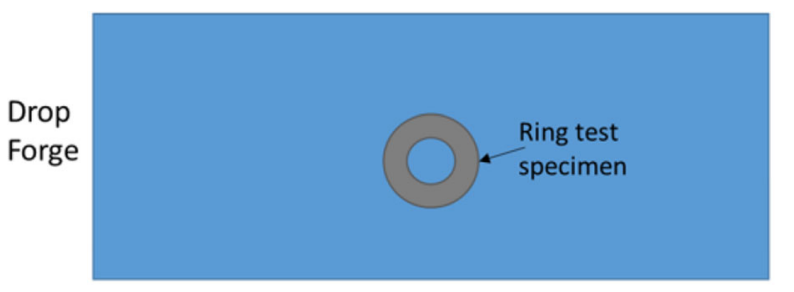

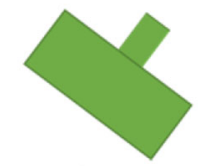

Thermal Imaging camera

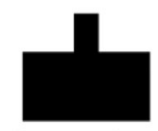

High speed camera

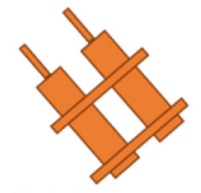

Lubricant spray equipment

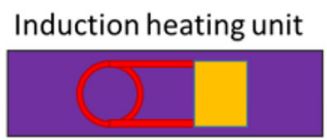

Fig. 3 Plan view of the equipment layout (not to scale)

the difference in volume between two circular rings. This yields a ring sample mass of $\sim 0.44 \mathrm{~kg}$.

From the literature [11] a temperature-dependent function for $c_{p}$ for carbon steels was obtained, given in Eq. 2.

$\begin{array}{rlrl}c_{p}=425+\left(7.73 \times 10^{-1} T\right)-\left(1.69 \times 10^{-3} T^{2}\right)+\left(2.22 \times 10^{-6} T^{3}\right) & & \text { for } 20^{\circ} \mathrm{C}<T<600^{\circ} \mathrm{C} \\ c_{p}=666+\frac{13002}{738-T} & & \text { for } 600^{\circ} \mathrm{C}<T<735^{\circ} \mathrm{C} \\ c_{p}=545+\frac{17820}{T-731} & & \text { for } 735^{\circ} \mathrm{C}<T<900^{\circ} \mathrm{C} \\ & c_{p}=650 & & \text { for } T>900^{\circ} \mathrm{C}\end{array}$

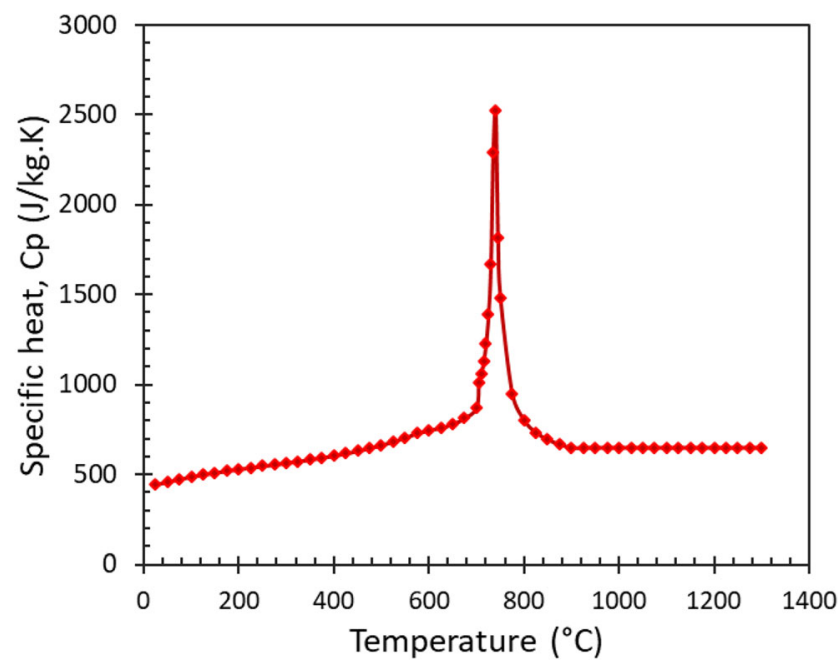

Fig. 4 Specific heat function for steels as taken from the literature [10]

These functions yield a temperature-dependent specific heat relationship as shown in Fig. 4. Note the broad peak at approximately 700 to $760^{\circ} \mathrm{C}$, which is the classical latent heat effect caused by solid state transformations.

One can then mathematically derive the total thermal energy to heat from room temperature to either $1030^{\circ} \mathrm{C}$ or 1300 ${ }^{\circ} \mathrm{C}$ for the steel, with the temperature-dependent specific heat term, which can be expressed as the integral of Eq. 1:

$Q_{\mathrm{TOT}}=m \int_{20}^{\text {soak }} c_{p}(T) \cdot d T$

which, once taking into consideration the different partitions of the function for specific heat, can be fully expressed as

$Q_{\text {тот }}=m\left[\int_{20}^{600}\left(425+0.773 T-\left(1.69 \times 10^{-3} T^{2}\right)+\left(2.22 \times 10^{-6} T^{3}\right)\right) \cdot d T+\int_{600}^{735}\left(666+\frac{13002}{738-T}\right) \cdot d T+\int_{735}^{900}\left(545+\frac{17820}{T-731}\right) \cdot d T+\int_{900}^{\text {soak }} 650 \cdot d T\right]$

which yields a solution as given in Eq. 5 .

$Q_{\text {Tот }}=m\left(\left[425 T+0.387 T^{2}-\left(0.563 \times 10^{-3} T^{3}\right)+\left(0.555 \times 10^{-6} T^{4}\right)\right]_{20}^{600}+[666 T-13002 \ln \{738-T\}]_{600}^{735}+[545 T+17820 \ln \{T-731\}]_{735}^{900}+[650 T]_{900}^{\text {soak }}\right)$

again where $T$ is the temperature and soak is the upper soak temperature, either $1030{ }^{\circ} \mathrm{C}$ or $1300^{\circ} \mathrm{C}$. The various partitions of the expression can be integrated to produce (i) a quartic function, (ii) and (iii) linear term and natural logs and (iv) a linear term for the four partitions respectively. Upon applying these functions at the relevant partition temperatures, and using the ring mass as calculated previously, then this firstprinciple methodology yields approximately $317 \mathrm{~kJ}$ of energy to heat the $1030{ }^{\circ} \mathrm{C}$ sample and approximately $394 \mathrm{~kJ}$ to heat the $1300{ }^{\circ} \mathrm{C}$ sample. If these values are compared with the those used in practice ( $350 \mathrm{~kJ}$ and $413 \mathrm{~kJ}$ respectively), then an excellent agreement is found for the $1300^{\circ} \mathrm{C}$ sample, and a small error of $\sim 33 \mathrm{~kJ}$ for the $1030{ }^{\circ} \mathrm{C}$ sample, likely caused by either small variation in the true specific heat function of this particular steel alloy or thermal inefficiency within the system. Lastly, given the constant power applied by the induction heating unit, one can assume that the energy is also constant. Thus, it is now possible to predict the experimental heating rate of the two samples accordingly (see Fig. 5). Both conditions produce similar heating rates, suggesting that this is not 


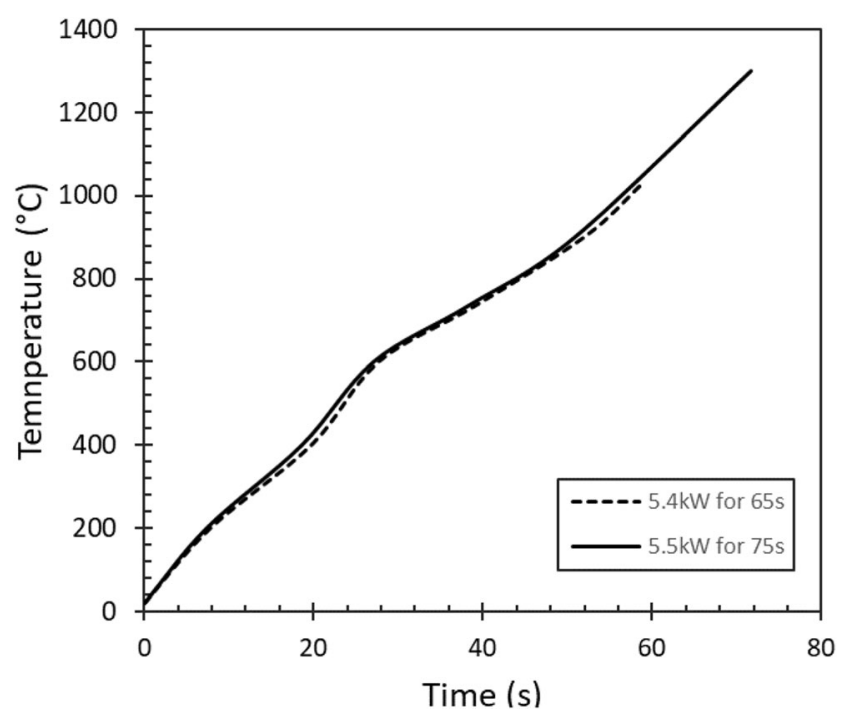

Fig. 5 Theoretically derived heating rates for the two samples

playing an important role in any observed mechanical property difference. Note that a slight slowing of heating rate is observed as the sample passes through the $\sim 700$ to $750{ }^{\circ} \mathrm{C}$ regime, due to the latent heat effect.

\section{Results and discussion}

\subsection{General appearance}

Once forged, each of the unlubricated, synthetic water-based and graphite water-based samples displayed a similar, evenly deformed profile. This is hypothesised to be due to the two water-based lubricants breaking down prior to the hammer blow being delivered. This conforms with work in the literature by Wan et al. [31], where an assessment of graphite only being effective up to temperatures of around $300{ }^{\circ} \mathrm{C}$ and synthetic to even lower temperature (Wan et al. [31]). The heated billet in this forging experiment would have been significantly higher than $300{ }^{\circ} \mathrm{C}$ when the lubricant was applied. Thus, it is believed that all water-based lubricant samples were, unknowingly at the time of forging, in the unlubricated condition (see Fig. 6a).

The sample which was forged using graphite and molybdenum disulphide viscous grease displayed a significantly different deformation pattern. The top of the sample had a distinctly more rounded edge at the top and a sharp edge at the bottom (see Fig. 6b). Although there were no visible difference in surface hardness, it is thought that the bottom die, upon which the sample was placed for a few seconds before the hammer blow was struck, could have been acting as a heat sink on the sample, therefore delivering a non-symmetric temperature field across the part and thus facilitating differing amounts of plastic deformation. However, this effect would in theory have been observed on the other forged rings with different lubricants as well, unless the graphite molybdenum disulphide grease acted as a thermal conductor. Another factor that may support the non-symmetric deformation is non-uniformity in grease lubricant application. Whilst every effort was made to apply a uniform coating of grease upon top and bottom dies, any temperature dependence of the grease's lubrication effect may play a role, due to the grease's contact with the heated dies.

Although nominally at the same temperature at the commencement of the experiment, if the top and base dies are cooling at fractionally different rates, due to external factors such as air circulation currents from open doors, or through elevated atmospheric temperatures at the additional $1.65 \mathrm{~m}$ height that the top die is held, so the grease may impart a different viscosity and different lubricant effect at the interface. Another possible explanation is that the grease lubricant brushed to the bottom die may have adhered better than the top die allowing more flow to occur at the bottom of the sample.

Visual differences were also apparent when comparing the surface condition of the top and bottom of each sample. The bottom of the samples displayed higher amounts of surface oxidation than the top. This is thought to have occurred because as the sample was sat on the die the scale was unable to
Fig. 6 Profile of deformed samples after forging using a unlubricated and $\mathbf{b}$ graphitemolybdenum disulphide lubricants

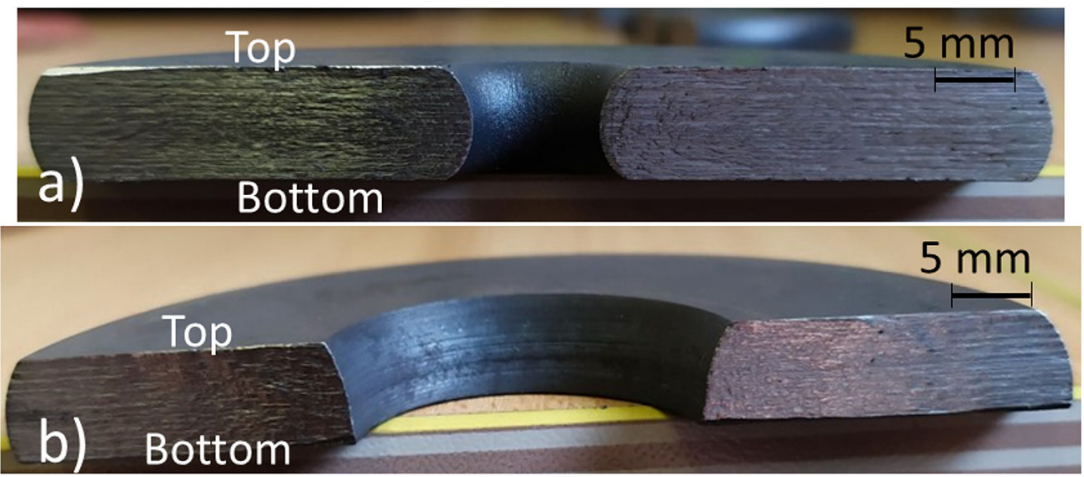


flake off and disconnect from the sample. Then, once forged, the scale embedded back into the part. During normal processing conditions air blasts would minimise this issue and disperse the scale; however, they were not switched on during this experiment to give the applied lubricant the best possible chance of forming a lubricating film. The operators were concerned that the air blasts could reduce the adherence of the lubricant.

Samples at the $1300{ }^{\circ} \mathrm{C}$ test temperature displayed higher amounts of oxidation due to the sample being heated to a higher temperature and for a longer duration during the induction heating method, being conducted with the sample in standard atmospheric conditions. The increased propensity for oxidation at elevated temperate has allowed for easier diffusion of the oxygen in the atmosphere to take place on the samples surface and significantly more oxide scale to form. Figure 7 displays these visual differences.

\subsection{Microstructure}

The microstructure present close to the surface, for a $708 \mathrm{M} 40$ steel sample heated by induction methods to $1030{ }^{\circ} \mathrm{C}$, a sample heated to $1300{ }^{\circ} \mathrm{C}$ and an unheated sample, was analysed using a JEOL 7000F scanning electron microscope (SEM). Samples were sectioned perpendicular to the upper surface, and a repeatable location $1.5 \mathrm{~mm}$ down from the upper surface was used. The resulting images are given in Fig. 8. The growth of the grains caused by the heating operation within the two heated samples is evident, when compared with the unheated sample.

There are a number of competing microstructural evolution mechanisms which influence the mechanical properties. The longer a sample is heated, and the higher the temperature, the bigger the grains can grow [5]. Thus, the microstructures have a lower volume fraction of grain boundaries, which provide strengthening mechanisms to the microstructure. However, as the material heats, it also experiences certain chemical elements precipitating out to form clusters of element-rich pinning sites. The deformation of the grain under impact from the forge hammer can also strain the material, causing strainhardening within the grain, through complex dislocation interactions [6].

\subsection{Surface hardness}

Surface hardness tests were performed to establish any differences regarding the top and bottom surfaces of each sample, hardness pre and post forging at the two test temperatures $\left(1030^{\circ} \mathrm{C}\right.$ and $\left.1300^{\circ} \mathrm{C}\right)$ and any variation in hardness between these samples. The significant effects that heat treatments can have upon hardness have been considered in the literature previously by Ismail et al. [14]. The results are presented in Tables 3 and 4. To assess repeatability for the surface hardness, values were taken at 5 equally spaced azimuthal locations around the flattened ring, all at the same radial value. Experimental variations are represented by standard deviation bars on resulting graphs in Fig. 9.

The average hardness for the as-forged samples conducted at $1030{ }^{\circ} \mathrm{C}$ compared with the pre-forged measurements do show a slight increase (see Fig. 9a). It is understood that there are two competing metallurgical phenomena occurring within the material, to generate these surface hardness values. The first driving mechanism for evolution of the hardness is the grain growth occurring in these samples, which has a direct impact on surface properties such as hardness. The coarser the grains are allowed to become, the lower the component hardness would be, and conversely the finer the grains the greater the component hardness would be.

Therefore, as the sample was heated it would soften. However, the second driving mechanism impacting the grain size is caused by the deformation due to forging. As the ring component was forged, the considerable deformation which took place compressed and refined the grains causing the sample to work-harden. These two conflicting phenomena cancelled each other out to the most extent with only a small residual decrease from the pre-forged sample hardness evident at the $1300{ }^{\circ} \mathrm{C}$ samples where the grain growth softening marginally dominates, and a small residual increase in surface hardness for the $1030{ }^{\circ} \mathrm{C}$ samples where the work-hardening marginally dominates.

By comparing the post-forging results for the $1030{ }^{\circ} \mathrm{C}$ and the $1300{ }^{\circ} \mathrm{C}$ samples, a significant difference in hardness is evident. This occurs as the $1300{ }^{\circ} \mathrm{C}$ heated ring sample allows for considerably greater grain growth phenomena to occur, compared with the $1030{ }^{\circ} \mathrm{C}$ sample. This in turn results in coarser grains leading to a lower hardness. As discussed
Fig. 7 Visual difference regarding oxide scale on a upper and $\mathbf{b}$ lower surfaces of a graphite-molybdenum disulphide forging
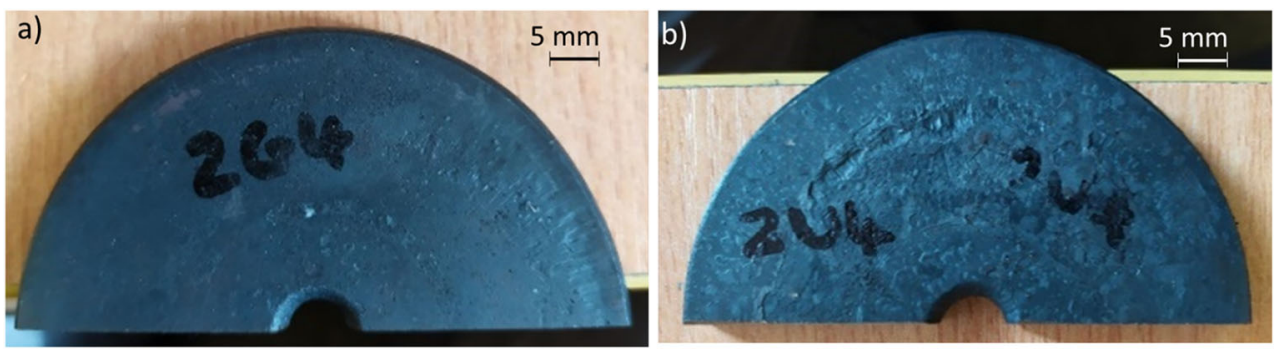
Fig. 8 Microstructure of 708M40 steel close to the surface, in a sample before Induction heating, b sample heated to $1030{ }^{\circ} \mathrm{C}$ and c sample heated to $1300{ }^{\circ} \mathrm{C}[28]$
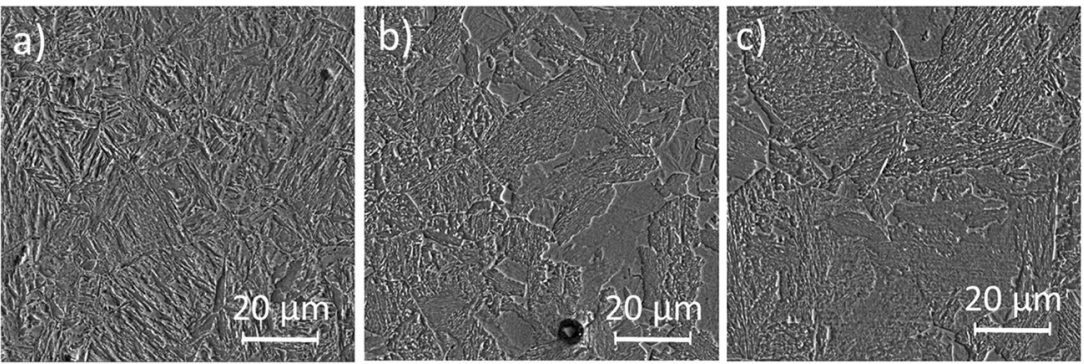

previously, it is believed that the two water-based lubricants evaporated before the forging occurred, so there was no real differences observed in terms of the unlubricated and the water-based lubricants used.

Due to the highly non-uniform deformation characteristic for the graphite-molybdenum disulphide grease samples, surface hardness tests were performed at locations on both the top and bottom surfaces of all these samples, in order to establish if there were any significant differences in hardness measurements. As before, these measurements were taken at the same radial distance away from the edge of the flattened ring specimens and were equally spaced through the azimuthal angular co-ordinate, at approximately $72{ }^{\circ} \mathrm{C}$. Figure $9 \mathrm{~b}$ displays the resulting hardness values.

It becomes evident from the results that at both temperatures for this lubricant, the post-forged samples had a slightly lower surface hardness value than before forging. Thus, it is assumed that the grain coarsening mechanism caused by the initial induction heating process is dominating the grain size competing mechanisms. The soak temperature has a much weaker effect than for the unlubricated and water-based lubricant experiments, with the mean upper and lower surface hardness values only reduced by $\sim 1.5$ to $5 \mathrm{HB}$, compared with the $\sim 25$ to 30 HB reduction experienced for the other lubricants. This may suggest at an improved thermal insulation property of the graphite molybdenum disulphide grease as an unexpected side effect.

\subsection{Surface roughness}

Surface roughness ( $\mathrm{Ra} 0.8$ ) tests were performed to establish any differences within the samples, regarding their (i) surface roughness pre-forging and post forging for samples as a function of the soak temperature used and (ii) surface roughness pre-forging and post forging for samples as a function of their lubricant agent. These are summarised in Table 5. Figure 10 illustrates the mean surface roughness results taken from the series of forging samples. It is evident that a significant increase in surface roughness is observed between the pre-forged and all post-forged samples. The deformation and shear mechanisms present within a bulk forging operation due to contact with tooling are the primary mechanism for increasing surface roughness.

Considering the samples forged at $1030^{\circ} \mathrm{C}$, for each lubricant a significant increase in surface roughness was measured. This is due to the surface layers of the samples oxidising, thus resulting in the increased surface roughness. This trend agrees with the findings of Markov et al. [20] for a different forging

Table 3 Results of surface hardness measurements, pre- and post-forging, for all 5 repeats, for the unlubricated, synthetic water-based and graphite water based lubricants, at $1030{ }^{\circ} \mathrm{C}$ and $1300{ }^{\circ} \mathrm{C}$

\begin{tabular}{|c|c|c|c|c|c|c|c|c|c|c|c|}
\hline \multirow[b]{2}{*}{$\begin{array}{l}\text { Temperature } \\
\left({ }^{\circ} \mathrm{C}\right)\end{array}$} & \multirow[b]{2}{*}{ Lubricant } & \multicolumn{2}{|l|}{-1} & \multicolumn{2}{|l|}{2} & \multicolumn{2}{|l|}{3} & \multicolumn{2}{|l|}{-4} & \multicolumn{2}{|l|}{5} \\
\hline & & $\begin{array}{l}\mathrm{H}_{\mathrm{B}} \text { (pre- } \\
\text { forge) }\end{array}$ & $\begin{array}{l}\mathrm{H}_{\mathrm{B}} \text { (post- } \\
\text { forge) }\end{array}$ & $\begin{array}{l}\mathrm{H}_{\mathrm{B}} \text { (pre- } \\
\text { forge) }\end{array}$ & $\begin{array}{l}\mathrm{H}_{\mathrm{B}} \text { (post- } \\
\text { forge) }\end{array}$ & $\begin{array}{l}\mathrm{H}_{\mathrm{B}} \text { (pre- } \\
\text { forge) }\end{array}$ & $\begin{array}{l}\mathrm{H}_{\mathrm{B}} \text { (post- } \\
\text { forge) }\end{array}$ & $\begin{array}{l}\mathrm{H}_{\mathrm{B}} \text { (pre- } \\
\text { forge) }\end{array}$ & $\begin{array}{l}\mathrm{H}_{\mathrm{B}} \text { (post- } \\
\text { forge) }\end{array}$ & $\begin{array}{l}\mathrm{H}_{\mathrm{B}} \text { (pre- } \\
\text { forge) }\end{array}$ & $\begin{array}{l}\mathrm{H}_{B} \text { (post- } \\
\text { forge) }\end{array}$ \\
\hline 1030 & Un-lubricated & 257 & 245 & 254 & 267 & 250 & 274 & 248 & 268 & 250 & 264 \\
\hline 1030 & $\begin{array}{l}\text { Synthetic } \\
\text { water-base }\end{array}$ & 255 & 268 & 265 & 274 & 261 & 257 & 256 & 251 & 249 & 251 \\
\hline 1030 & $\begin{array}{l}\text { Graphite } \\
\quad \text { water-based }\end{array}$ & 262 & 271 & 260 & 260 & 261 & 272 & 257 & 273 & 243 & 284 \\
\hline 1300 & Un-lubricated & 253 & 206 & 248 & 236 & 245 & 210 & 252 & 235 & 251 & 249 \\
\hline 1300 & $\begin{array}{l}\text { Synthetic } \\
\text { water-based }\end{array}$ & 249 & 235 & 243 & 226 & 257 & 237 & 262 & 245 & 245 & 235 \\
\hline 1300 & $\begin{array}{l}\text { Graphite } \\
\text { water-based }\end{array}$ & 264 & 243 & 245 & 237 & 240 & 235 & 261 & 241 & 244 & 223 \\
\hline
\end{tabular}


Table 4 Results of surface hardness measurements, pre-forging, and post forging top and bottom surfaces, for all 3 repeats, for the graphite molybdenum disulphide grease, at $1030{ }^{\circ} \mathrm{C}$ and $1300{ }^{\circ} \mathrm{C}$

\begin{tabular}{|c|c|c|c|c|c|c|c|c|c|c|}
\hline \multirow[b]{2}{*}{$\begin{array}{l}\text { Temperature } \\
\left({ }^{\circ} \mathrm{C}\right)\end{array}$} & \multirow[b]{2}{*}{ Lubricant } & \multicolumn{3}{|l|}{-1} & \multicolumn{3}{|l|}{${ }_{-2}^{2}$} & \multicolumn{3}{|l|}{-3} \\
\hline & & $\begin{array}{l}\mathrm{H}_{\mathrm{B}} \text { (pre- } \\
\text { forge) }\end{array}$ & $\begin{array}{l}\mathrm{H}_{\mathrm{B}} \text { Top } \\
\text { (post-forge) }\end{array}$ & $\begin{array}{l}\mathrm{H}_{\mathrm{B}} \mathrm{Btm} \\
\text { (post-forge) }\end{array}$ & $\begin{array}{l}\mathrm{H}_{\mathrm{B}} \text { (pre- } \\
\text { forge) }\end{array}$ & $\begin{array}{l}\mathrm{H}_{\mathrm{B}} \text { Top } \\
\text { (post-forge) }\end{array}$ & $\begin{array}{l}\mathrm{H}_{\mathrm{B}} \mathrm{Btm} \\
\text { (post-forge) }\end{array}$ & $\begin{array}{l}\mathrm{H}_{\mathrm{B}} \text { (pre- } \\
\text { forge) }\end{array}$ & $\begin{array}{l}\mathrm{H}_{\mathrm{B}} \text { Top } \\
\text { (post-forge) }\end{array}$ & $\begin{array}{l}\mathrm{H}_{\mathrm{B}} \mathrm{Btm} \\
\text { (post-forge) }\end{array}$ \\
\hline 1030 & $\begin{array}{c}\text { Graphite-molyb. } \\
\text { grease }\end{array}$ & 245 & 230.8 & 253.6 & 245 & 258.2 & 228.8 & 245 & 227 & 232.2 \\
\hline 1300 & $\begin{array}{c}\text { Graphite-molyb. } \\
\text { grease }\end{array}$ & 251 & 230 & 232.8 & 251 & 237.6 & 225.6 & 245 & 214 & 232.6 \\
\hline
\end{tabular}

operation. The increase in surface roughness measurements for samples using all lubricants was even more pronounced for the $1300{ }^{\circ} \mathrm{C}$ soak temperature samples; for example, the unlubricated samples increased from a pre-forging roughness value of $0.5 \mu \mathrm{m}$, to $1.5 \mu \mathrm{m}$ for the $1030{ }^{\circ} \mathrm{C}$ soak, to $2.0 \mu \mathrm{m}$ for the $1300{ }^{\circ} \mathrm{C}$ soak temperature.
Fig. 9 (a) Mean pre-forge and post-forging surface hardness measurements, within each experimental group, for the unlubricated, synthetic waterbase and graphite water-base experiments, at both $1030{ }^{\circ} \mathrm{C}$ and $1300{ }^{\circ} \mathrm{C}$. (b) Mean pre-forge, post-forging top surface and postforging bottom surface hardness measurements, for the graphitemolybdenum disulphide grease samples, at both $1030{ }^{\circ} \mathrm{C}$ and $1300{ }^{\circ} \mathrm{C}$

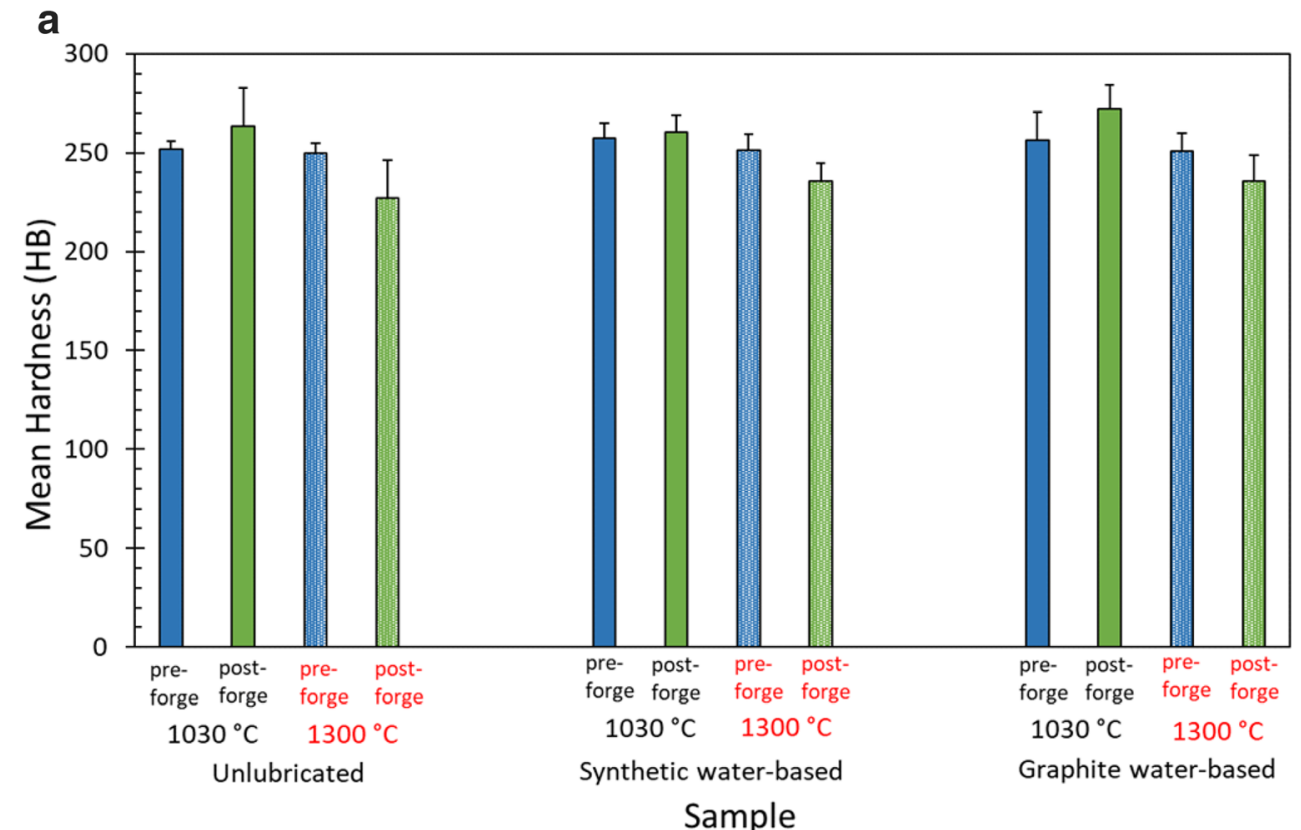

b

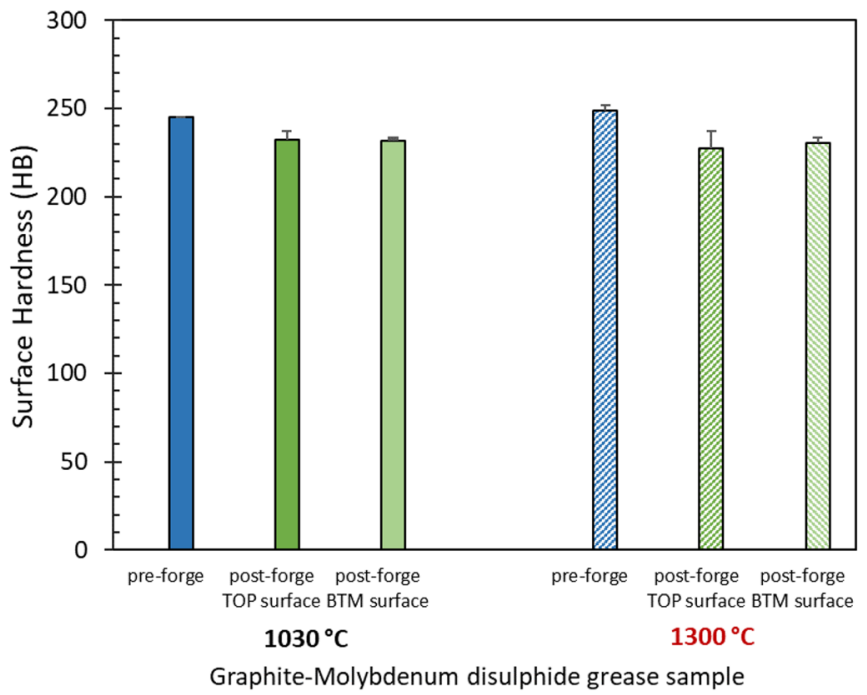


Table 5 Results of surface roughness measurements, pre- and post-forging, for all repeats, for the unlubricated, synthetic water-based and graphite water based, and graphite molybdenum disulphide grease lubricants, at $1030{ }^{\circ} \mathrm{C}$ and $1300{ }^{\circ} \mathrm{C}$.

\begin{tabular}{|c|c|c|c|c|c|c|c|c|c|c|c|}
\hline \multirow[b]{2}{*}{$\begin{array}{l}\text { Temperature } \\
\left({ }^{\circ} \mathrm{C}\right)\end{array}$} & \multirow[b]{2}{*}{ Lubricant } & \multicolumn{2}{|l|}{-1} & \multicolumn{2}{|l|}{$\_^{2}$} & \multicolumn{2}{|l|}{-3} & \multicolumn{2}{|l|}{-4} & \multicolumn{2}{|l|}{-5} \\
\hline & & $\begin{array}{l}\mathrm{Ra} 0.8 \\
\text { (pre- } \\
\text { forge) }\end{array}$ & $\begin{array}{l}\text { Ra0.8 } \\
\text { (post- } \\
\text { forge) }\end{array}$ & $\begin{array}{l}\mathrm{Ra} 0.8 \\
\text { (pre- } \\
\text { forge) }\end{array}$ & $\begin{array}{l}\mathrm{Ra} 0.8 \\
\text { (post- } \\
\text { forge) }\end{array}$ & $\begin{array}{l}\text { Ra0.8 } \\
\text { (pre- } \\
\text { forge) }\end{array}$ & $\begin{array}{l}\mathrm{Ra} 0.8 \\
\text { (post- } \\
\text { forge) }\end{array}$ & $\begin{array}{l}\mathrm{Ra} 0.8 \\
\text { (pre- } \\
\text { forge) }\end{array}$ & $\begin{array}{l}\text { Ra0.8 } \\
\text { (post- } \\
\text { forge) }\end{array}$ & $\begin{array}{l}\mathrm{Ra} 0.8 \\
\text { (pre- } \\
\text { forge) }\end{array}$ & $\begin{array}{l}\text { Ra0.8 } \\
\text { (post- } \\
\text { forge) }\end{array}$ \\
\hline 1030 & Un-lubricated & 0.32 & 1.64 & 0.65 & 1.33 & 0.68 & 0.88 & 0.45 & 1.49 & 0.48 & 1.36 \\
\hline 1030 & $\begin{array}{l}\text { Synthetic } \\
\text { water-base }\end{array}$ & 0.56 & 2.34 & 0.47 & 2.42 & 0.66 & 1.45 & 0.75 & 1.71 & 0.32 & 1.35 \\
\hline 1030 & $\begin{array}{l}\text { Graphite } \\
\text { water-base }\end{array}$ & 0.88 & 1.61 & 0.44 & 1.06 & 0.36 & 1.34 & 0.3 & 0.9 & 0.44 & 1.59 \\
\hline 1030 & $\begin{array}{l}\text { Molybdenum } \\
\text { disulphide. } \\
\text { grease }\end{array}$ & 0.56 & 3.38 & 0.44 & 3.31 & 0.47 & 2.85 & N/A & N/A & N/A & N/A \\
\hline 1300 & Un-lubricated & 0.68 & 1.23 & 0.64 & 1.13 & 0.78 & 2.21 & 0.54 & 3.6 & 0.47 & 1.74 \\
\hline 1300 & $\begin{array}{l}\text { Synthetic } \\
\text { water-base }\end{array}$ & 0.45 & 1.21 & 0.53 & 2.5 & 0.36 & 3.1 & 0.7 & 4.04 & 0.75 & $2 . .29$ \\
\hline 1300 & $\begin{array}{l}\text { Graphite } \\
\quad \text { water-base }\end{array}$ & 0.64 & 2.49 & 0.74 & 2.22 & 0.4 & 2.23 & 0.39 & 3.46 & 0.46 & 1.79 \\
\hline 1300 & $\begin{array}{l}\text { Molybdenum } \\
\text { disulphide. } \\
\text { grease }\end{array}$ & 0.45 & 4.67 & 0.43 & 3.96 & 0.44 & 4.31 & $\mathrm{~N} / \mathrm{A}$ & N/A & $\mathrm{N} / \mathrm{A}$ & N/A \\
\hline
\end{tabular}

As for the surface hardness results, there are only very small variations in the data for unlubricated, synthetic water-based and graphite water-based lubricants. With no clear trend evident, it again points to the conclusion that the two water-based lubricants were evaporated off the sample prior to forging. However, the graphite-molybdenum disulphide grease sample illustrates a significantly higher increase in the post-forged surface roughness values, at both soak temperatures This suggests that the greater the deformation within the sample, facilitated by a lower frictional value at the tooling to billet interface, the greater the increase in surface roughness.

\section{Conclusion}

A series of compression tests were performed on BS970:708M40 steel ring specimens measuring $32.5 \mathrm{~mm}$ ID, $65 \mathrm{~mm}$ OD and $20 \mathrm{~mm}$ in height. The resulting compressed samples were analysed for surface hardness and surface roughness properties. The following conclusions are drawn from this study.

- Oxide scaling is more prevalent on the surface of forging induction heated to higher temperature. This is due to the increased oxygen diffusion of steels when at elevated
Fig. 10 Mean pre-forge and postforging roughness measurements, for the unlubricated, synthetic water-base, graphite water-base and molybdenum disulphide experiments, at both $1030^{\circ} \mathrm{C}$ and $1300{ }^{\circ} \mathrm{C}$

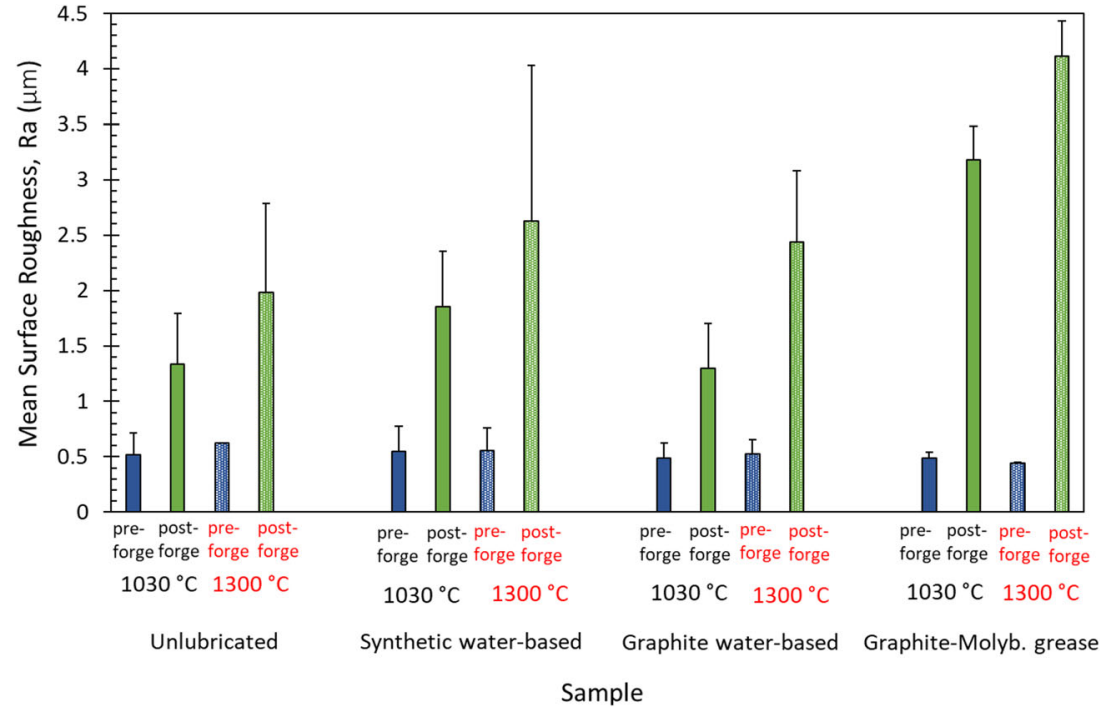


temperature. Scale also had a tendency to form in greater quantity on the bottom surface. This may be due to the significantly longer contact time with the bottom-die base than the top die.

- The drop forging operation, which induces significant strain within the workpiece, can cause strain hardening effects within the steel, through dislocation interactions.

- Surface hardness decreases with increasing temperature and longer soak time. This metallurgical phenomenon occurs because the short tempering heat treatment operation which the induction heating can be considered as, allows for dissolution of precipitates in the microstructure. Whilst the $1030^{\circ} \mathrm{C}$ induction heating has allowed for the classical precipitation hardening at the surface, the additional heating to $1300{ }^{\circ} \mathrm{C}$ has led to excessive precipitate dissolution which results in reduced hardness.

- Surface roughness of a machined specimen increases through bulk forming operations, due to the frictional contact with heavy tooling, and due to large deformation mechanisms acting upon the billet. At higher temperatures the increase in the surface roughness is exacerbated.

- Water-based lubricants appear to be relatively ineffective as forging lubricant agents when used in high-temperature applications when there is a delay between lubricant application and forging blow. This is because the dwell time of the lubricant resting upon the $100^{\circ} \mathrm{C}$ flat die and hammer after spraying evaporates the water base.

\section{Recommendations}

- As water-based lubricants have shown to break down when in contact with high temperature billets it is critical to establish timescales of which forging needs to occur in relation to the lubricant being applied.

- Extending out the temperatures under investigation to cover a wider range of forging temperatures, and with smaller steps, would further populate the scientific understanding on the impact that forging temperature plays on property.

- Dependant on sample chemical composition frictional values could be radically different. Low carbon material will not oxide scale as much as those materials that contain higher amounts of carbon. This is due to carbon having a high affinity for oxygen. This lower displayed oxide scaling could produce differing deformation amounts. Testing could be performed using different materials to gauge a good working practice guide to aide forging operatives.

- In the same way the sample surface roughness could affect the tribological nature of the process, the tool surface roughness could also impact as highly. Tests could be performed to establish the impacts surface roughness of tooling has on tribology in forging.

- As it is expected that the lubricant vaporises at the sample heated surface, perhaps SEM-EDS could be performed on samples where lubricant was applied to the sample with it then being deformed. This could lock in place some of the additional carbon atoms into the sample's substrate allowing the SEM-EDS to identify the additional carbon. This is a thought that could easily be concluded with additional testing performed on the already forged samples.

Acknowledgements The authors thank WH Tildesley Ltd for technical advice and use of equipment during this project. Thanks are also offered to Wolverhampton University who facilitated the degree programme, which this work formed a technical component.

Funding The authors were financially supported by WH Tildesley Ltd.

Open Access This article is licensed under a Creative Commons Attribution 4.0 International License, which permits use, sharing, adaptation, distribution and reproduction in any medium or format, as long as you give appropriate credit to the original author(s) and the source, provide a link to the Creative Commons licence, and indicate if changes were made. The images or other third party material in this article are included in the article's Creative Commons licence, unless indicated otherwise in a credit line to the material. If material is not included in the article's Creative Commons licence and your intended use is not permitted by statutory regulation or exceeds the permitted use, you will need to obtain permission directly from the copyright holder. To view a copy of this licence, visit http://creativecommons.org/licenses/by/4.0/.

\section{References}

1. Allam Z, Becker E, Baudouin C, Bigot R, Krumpipe P (2014) Forging Process Control: Influence of Key Parameters Variation on Product Specifications Deviations, Procedia Engineering 81: 2524-2529. https://doi.org/10.1016/j.proeng.2014.10.361

2. Bhadeshia H, Honeycombe R (2017) Steels: microstructure \& properties, 4th edn. Butterworth-Heinemann, UK

3. Bouissa Y, Bohlooli N, Shahriari D, Champliaud H, Morin J-B, Jahazi M (2020) FEM modeling and experimental validation of quench-induced distortions of large size steel forgings. Manuf Process 58:592-605

4. Bourebia M, Meddah S, Hamadache H, Taleb A, Gharbim A, Laouar L (2019) Effect of heat treatment on surface hardness and tribological behavior of XC38 steel — approach by the experiments plans. Mater Res Express 6:7

5. Chen RC, Hong C, Li JJ, Zheng ZZ, Li PC (2017) Austenite grain growth and grain size distribution in isothermal heat-treatment of 300M steel. Proceedia Eng 207:663-668

6. Dastur YN, Leslie WC (1981) Mechanism of work hardening in Hadfield manganese steel. Met Trans A 12A:749-759

7. Dinesh Kumar S, Purushothaman K, Chandramohan D, MohinishDushyantraj M, Sathish T (2020) ANN-AGCS for the prediction of temperature distribution and required energy in hot forging process using finite element analysis. Mater Today 21(1):263-267

8. Doege E, Bohnsack R (2000) Closed die technologies for hot forging. Mater Proc Technol 98:165-170

9. Douglas R, Kuhlmann D (2000) Guidelines for precision hot forging with applications. Mater Proc Technol 98:182-188 
10. Franssen, J-M., Vila Real, P., (2013) Fire Design of Steel Structures: Eurocode 1: Actions on structures Part 1-2 - General actions - Actions on structures exposed to fire Eurocode 3: Design of steel structures Part 1-2 - General rules - Structural fire design, Annex A: Thermal Data for Carbon Steel and Stainless Steel Sections 319-345. https://doi.org/10.1002/9783433601570.app1

11. Groche P, Müller C, Jahn A (2014) Effects of the tool lubrication in cold forging. Tribol Lett 53:599-605. https://doi.org/10.1007/ s11249-014-0297-0

12. Gronostajski Z, Kaszuba M, Polak S, Zwierzchowski M, Niechajowicz A, Hawryluk M (2016) The failure mechanisms of hot forging dies: Mater. Sci. Eng.: A, 657, pp.147-160. https://doi. org/10.1016/j.msea.2016.01.030

13. Hillfoot Metals, Sheffield, UK. 708M40 datasheet. https://www. hillfoot.com/products/708m40-chromium-molybdenum-throughhardening-steel. Accessed Dec 2020

14. Ismail NM, Aida N, Khatif A, Kecik MAKA, Shaharudin MAH (2016) The effect of heat treatment on the hardness and impact properties of medium carbon steel. IOP Conf Series: Mater Sci Eng 114. https://doi.org/10.1088/1757-899X/114/1/012108

15. Jahazi M, Eghbali B (2001) The influence of hot forging conditions on the microstructure and mechanical properties of two microalloyed steels. J Mater Process Technol 113(1):594-598. https://doi.org/10.1016/S0924-0136(01)00599-4

16. Jang Y-S, Ko D-C, Kim B-M (2000) Application of the finite element method to predict microstructure evolution in the hot forging of steel. Mater Proc Technol 101(1-3):85-94

17. Jeong JD, Kim JD, Kim HJ, Kim MB, Dean AT (2001) Effects of surface treatments and lubricants for warm forging die life. J Mater Proc Technol 113(1-3):544-550. https://doi.org/10.1016/S09240136(01)00693-8

18. Larrabee S (2013) Control, Repeatability are name of the game with Induction Heat Treating, Industrial Heating. https://www. industrialheating.com/articles/91415-control-repeatability-arename-of-the-game-with-induction-heat-treating. Accessed Dec 2020

19. Linaza MA, Romero JL, Rodriguez-Ibabe JM, Urcola J (1993) Improvement of fracture toughness of forging steels microalloyed with titanium by accelerated cooling after hot working, Scripta Metall. Mater. 29:1217-1222

20. Markov OE, Gerasimenko O, Aliieva L, Shapoval A, Kosilov M (2019) Development of a new process for expanding stepped tapered rings. East-Eur J Enterp Technol 2(1-98):39-46. https://doi. org/10.15587/1729-4061.2019.160395

21. Markov OE, Perig AV, Zlygoriev VN, Markova MA, Kosilov MS (2017) Development of forging processes using intermediate workpiece profiling before drawing: research into strained state. J Braz
Soc Mech Sci Eng 39(11):4649-4665. https://doi.org/10.1007/ s40430-017-0812-y

22. Markov OE, Oleshko MV, Mishina VI (2011) Development of energy-saving technological process of shafts forging weighing more than 100 tons without ingot upsetting. Metall Min Ind 3(7): $87-90$

23. Matsumoto R, Osumi Y, Utsunomiya H (2014) Reduction of friction of steel covered with oxide scale in hot forging. Materials Proc. Tech. 214(3):651-659. https://doi.org/10.1016/j.jmatprotec.2013. 10.011

24. Rasouli D, Khamenah Asl S, Akbarzadeh A, Daneshi GH (2008) Effect of cooling rate on the microstructure and mechanical properties of microalloyed forging steel. Mater Proc Technol 206(1-3): 92-98

25. Standards UK (2019) Wrought steels for mechanical and allied engineering purposes. Requirements for carbon, carbon manganese and alloy hot worked or cold finished steels. https://www. standardsuk.com/products/PD-970-2005. Accessed Dec 2020

26. Stelstocks Ltd (2019) Brierley Hill, UK. https://www.stelstocks.co. uk/stock-range/708m40-709m40-en19-42crmos4/

27. Switzner NT, Vantyne C, Mataya MC (2010) Effect of forging strain rate and deformation temperature on the mechanical properties of warm-worked 304L stainless steel. J Mater Process Technol 210(8):998-1007. https://doi.org/10.1016/j.jmatprotec.2010.01. 014

28. Thirunavukkarasu G (2019) AMCASH Technical Report. University of Birmingham

29. Upadhya JC, Naik SS, Khedikar WK, Sudersanan M, Mathur PK (1999) Analysis of sulphur, phosphorus, and silica in metals, alloys and solvents. Technical report of Bhabha Atomic Research Centre, India BARC/1999/E/031. https://www.inis.iaea.org/collection/ NCLCollectionStore. Accessed July 2020

30. Utsunomiya H, Doi S, Hara K, Sakai T, Yanagi S (2009) Deformation of oxide scale on steel surface during hot rolling. CIRP Ann 58:271-274. https://doi.org/10.1016/j.cirp.2009.03.050

31. Wan S, Tieu KA, Xia Y, Zhu H, Tran HB, Cui S (2016) An overview of inorganic polymer as potential lubricant additive for high temperature tribology. Tribology Int [online] 102:620-635. https:// doi.org/10.1016/j.triboint.2016.06.010

32. Xu D, Li J, Meng Q, Liu Y, Li P (2014) Effect of heating rate on microstructure and mechanical properties of TRIP-aided multiphase steel. J Alloys Compd 614:94-101

Publisher's note Springer Nature remains neutral with regard to jurisdictional claims in published maps and institutional affiliations. 